\title{
ДОРОГА ЯК ЧАСТИНА КУЛЬТУРНОГО ЛАНДШАФТУ НОРВЕГІЇ: ЗМІНА СВІТОГЛЯДНОї ПАРАДИГМИ
}

\author{
- Сом-Сердюкова Олена Миколаївна \\ - Кандидат мистецтвознавства, доцент, \\ ORCID: 0000-0001-5196-545X, e-mail: olenasom@gmail.com, \\ Київський національний університет культури і мистецтв, \\ вул. Є. Коновальця, 36, Київ, Україна, 01133
}

\section{- Для цитування:}

Сом-Сердюкова, О.М. (2020). Дорога як частина культурного ландшафту Норвегії: зміна світоглядної парадигми. Питання культурологіï, (36), 147-155. doi: https://doi. org/10.31866/2410-1311.36.2020.221058.

\section{- Анотація}

Мета статті - визначити тенденції, особливості та функції доріг Норвегії, що є частиною формування культурного ландшафту. Дослідження побудоване на міждисциплінарному підході та використанні таких методів, як: аналітичний, систематичний, інтерпретаційний, описовий та діахронний - для підкреслення соціально-історичного контексту та розкриття явища дороги як цивілізаційного феномена, де зустрічаються культура і природа у формі діалогу. Наукова новизна роботи полягає у тому, що в ній вперше у вітчизняній науці досліджено феномен Національних туристичних доріг Норвегії, як організаційного чинника культурного ландшафту. Висновки. В сучасній Норвегії до доріг висуваються вимоги: зручності, безпеки, комфорту, етики взаємодії учасників руху, пізнання культурного ландшафту, естетики, видовища. Їх значущість для суспільства активізується, акумулюється та актуалізується. Схарактеризовано найбільш виразні проєкти, приділено увагу їх специфіці та оригінальності. Унікальності природи запропоновані унікальні об'єкти дизайну та мистецтва, саме для підвищення її виразності. Проаналізовано різноманітні способи делікатного вторгнення у природу, які демонструють транзитивність культури на тлі вічності. Локальний та міжнародний туризм як форма дозвілля стрімко набирає обертів, а розвиток туристичних доріг стимулює інфраструктуру. Їх функція розуміється через екологію, інформацію, дизайн, мистецтво. Таке ставлення до доріг передбачає не прагматичний підхід, що домінував раніше. Зазначено, що зміни у суспільстві вплинули на розуміння функції дороги. На сучасному етапі її життєдіяльність забезпечується спеціалістами різного профілю та доводить необхідність їі розуміння у синтезі логіки, естетики та емоції. Під час дослідження доведено значущість загальнодержавного проєкту Норвегії по удосконаленню та розширенню функції дороги. Визначено, що цей досвід за своїм значенням переростає межі національного проєкту.

Ключові слова: туристична дорога; культурний ландшафт; дизайн; мистецтво; природа; середовище 


\section{- Вступ}

Протягом останніх двадцяти років у Норвегії здійснюється масштабний проєкт по оснащенню Національних туристичних доріг, значення якого впливає на процес фрормування культурного ландшафту. Засобами дизайну та мистецтва розширюється функціональна приналежність доріг, що чітко відповідає зміненій парадигмі свідомості на зламі XX та XXI ст. Їх значущість для суспільства активізується, акумулюється та актуалізується. Естетизація дороги, насичення ії комфортом та додатковими можливостями для споглядання краси природи, розуміння її через призму екологічних проблем, є реаліями Норвегії. Знання цієї практики має допомогти українцям, які чітко обрали Західний вектор розвитку, сформувати подібне міждисциплінарне ставлення до дороги, як об'єкта культури. Це дасть можливість розвивати інфраструктуру, туризм, музейництво і має відповідати вимогам децентралізації влади.

Д. Гессен (Hessen, 2016) комплексно та системно висвітлює питання, що стосуються змін у ландшафті Норвегії. Культурний ландшафт досліджується у світі актуальних проблем географії, екології, історії та соціології. Особливу увагу приділено «локальній складовій» культурного ландшафту. I дорога, у даному контексті, виконує об'єднуючу функцію від місцевого до загальнодержавного значення. Питанню культурного ландшафту, систематизації вимог до сучасних доріг, означенню соціокультурних особливостей норвежців, приділено увагу у книзі Булла і Норвіка (Bull \& Norvik, 2004). Презентація виконаних об'єктів та проєктів, які будуть втілені найближчим часом, подана у каталозі «Туристичні дороги» (Andersen et al., 2016). Аналізуючи особливості норвезького дизайну та його естетичну залежність від краси природи, С. Бенгтсон (Bengtsson \& Zetterström, 2011) дає детальну характеристику декількох об'єктів з загальнодержавного проєкту по удосконаленню доріг.

\section{- Мета статті}

Визначити тенденції, особливості та функції доріг Норвегії, що є частиною формування культурного ландшафту; дослідити як змінюється світоглядна парадигма та їх феноменологія, виходячи з вимог сучасності: безпека, комфорт, екологія, естетика. Завданням $€$ схарактеризувати принципи, за якими проводиться у Норвегії переоснащення доріг; зосередити увагу на реалізації проєкту Національних туристичних доріг; узагальнити досвід включення елементів дизайну та мистецтва, які стають органікою дороги та збагачують культурний ландшафт. У дослідженні було використано такі методи, як: аналітичний, систематичний, інтерпретаційний, описовий та діахронний - для підкреслення соціально-історичного контексту. Вивчення аналітичних джерел та власні спостереження дали можливість розкрити явище дороги як цивілізаційного феномена, де зустрічаються культура і природа у формі діалогу.

\section{- Виклад матеріалу дослідження}

Норвегія (Norway, Norge) у буквальному розумінні $є$ дорогою на північ. Дорога визначила свідомість країни, закріпила та сформувала націю. Дорога залишається актуальним чинником єдності, добробуту, безпеки та естетичних вра- 
жень. 3 поправкою на те, що у давні часи та у добу Середньовіччя, яке у Норвегії мало затяжний характер, пересування здійснювалося водним шляхом, тобто по морю чи по фріордах. Відповідно інфраструктура країни майже до середини XIX ст. розвивалась вздовж узбережжя, де вхід углиб країни забезпечували рукави фріордів.

Кардинальне переформатування зв'язків та комунікативних з'єднань збіглося з ходою капіталізму та добою модернізму. Розпочиналась епоха «бачення» власної країни з інтер'єрної перспективи. Це поставило нові складні завдання будівництва доріг по всій країні. Розуміючи, що об'єктивна даність ландшафту це домінанта гірських масивів найрізноманітніших профрілів, то амбітне завдання «оселити» дорогу, стало проєктом сторіччя.

Сучасні дороги Норвегії вирізняються бездоганною якістю, ідеальним покриттям, але залишаються складними через нескінченну гнучкість ліній та неможливість їх розширити. Дорога-змія у поєднанні з численними поромами, тунелями та мостами - це даність країни. Особливою виразністю відрізняються численні мости. Інженерні конструкції кожного узгоджено з естетичною формулою та вдало вписано у конкретний пейзаж. I ця тенденція наближення до гармонії ліній постійно удосконалюється та наростає. Можна казати, що 1960-1990-ті роки було витрачено на досягнення прагматичної мети: пронизати країну тонким павутинням якісних та безпечних доріг. Це дало змогу утримати децентралізовану модель суспільного існування.

Наступним етапом стала зміна парадигми у напрямку естетичного контенту дороги. В 1993 році головною метою було визначення списку для надання цим шляхам статусу Національних туристичних. Проте передбачалось включити в нього тільки діючі - принципово не будувати нових, штучних, суто туристичних. Це мали бути напрацьовані артерії країни.

Було обрано 18 доріг за принципом «best of the best» з точки зору видовища. Загальна довжина шляхів - 1634 км. На них за планом, протягом 30 років, передбачалось звести 250 зон відпочинку та панорамні майданчики. Більшість з обраних доріг було побудовано у 1880-1940-х роках і вони потребували реконструкції, що й стало частиною плану. «Однією з цілей цього державного проєкту було стимулювання нових підприємців до участі на певних частинах доріг та інвестування в них» (Bengtsson \& Zetterström, 2011, s. 73).

За цим планом передбачалось відновлювати всі пошкодження природи та жодним чином не порушувати попередньо створений культурний ландшафт. Філософрія цього $є$ розуміння, що елементи природи, які мають важливе значення, разом з формами культури, знаходяться у постійній взаємозалежності та, відповідно, не можуть розглядатися окремо. Історичні свідчення у взаємодії з сучасною естетикою, стають плідним ґрунтом для засвоювання континууму та контенту кожного окремого культурного ландшафту.

Мета загальнодержавного проєкту туристичних доріг була сформульована так: продукт та метод виконання мають бути перфекціоністськими. Базисом програми стало розуміння, що туристична галузь набирає швидких обертів; мотиватором - ставлення норвежців до власної країни та бажання подорожувати нею. Передбачувалось, що проєкт об'єднає всю країну та стане справжнім 
національним надбанням. Дорога як головний компонент проєкту у поєднанні з визначною природою, архітектурою та мистецтвом мала сформувати новий погляд на Норвегію. Було зроблено акцент на внутрішньому туризмі, однак поступова реалізація проєкту і його популяризація залучила значну кількість іноземних туристів.

Думати про природу, отримати враження від ландшафту, розвивати екологічність масової свідомості - виховна місія проєкту. «Новітні дослідження вказують, що норвежці зосереджені на збереженні чистої природи, яка є для них найвищим досягненням якості життя. Занурення у чистоту природи, подорож у ліс чи на гору для отримання миру у душі. Те, що ми називаємо життя на свіжому повітрі, практикують дев'ять з десяти норвежців» (Bull \& Norvik, 2004, s. 215). І дорога $є$ інструментом для реалізації цих дій.

Розуміння цього проєкту, як важливого чинника фрормування культурного ландшафту, передбачає планування, будівництво, реконструкцію, поновлення, утримання та збереження дороги і її інфраструктури. Розглядались різні перспективи ії опрацювання: отримання вражень від природи, надання практичних зручностей, відчуття комфорту та задоволення від подорожі. А після її завершення мали залишатись приємні враження, які мотивували б на продовження.

Пілотний проєкт стартував 1997 року. Його здійснили молоді архітектори Ян Улав Йєнсен та Карл-Віго Хйолмебак на Старій Стрюнеф'єль дорозі. Ця команда зробила свій внесок в оформлення, зміну середовища засобами інноваційного архітектурного дизайну, який поєднується з природою. Було змінено тенденцію опорядження дороги, як чистого функціонала, на елемент демонстрації високої культури та розуміння естетики природи, коли людська творчість долучається до загальної гармонії та створює культурний ландшафт.

Бюро Jensen \& Skodvin реалізувало два проєкти. Зону відпочинку у Ліасанден (район Согнеф'єль) виконано з дерева, що гармонійно поєднується з видом окультуреного соснового лісу. Простота та лаконізм екстер'єрів дерев'яних будиночків з навісами доповнюється очікуваними зручностями цивілізації в інтер'єрі. Численні Z-подібні столи з лавками розміщено за принципом приватності, тобто на певних відстанях один від одного. Другий проєкт - це панорамний майданчик біля водоспаду Відефосен на Старій Стрюнеф'єль дорозі. Тут форма Z багаторазово повторюється у гнучкій стежці до водоспаду, що відкриває різні ракурси для милування могутньою енергією води. Чистота води у природі, можливість пити воду з крана вирізняє сучасну Норвегію 3-поміж інших країн. Особливо, якщо згадати контекст нашої планети. «Доступ до води, наявність питної води, підняття рівня води, наростання потопів, обробка відходів та забруднення води, розглядаються як найбільша турбота зламаної планети» (Fitz \& Krasny, 2019, р. 17). Матеріали, які використано для цих проєктів говорять мовою природи та співпадають з її колоритом. Це дерево, каміння з втручанням бетону та рустоване залізо. Ці об'єкти існують понад 20 років, проте їх естетика, спрямована на «нову» етику XXI ст., виправдала себе у часі. I ця тенденція стала провідною у видозмінах культурного ландшафту в межах усього проєкту.

В районі Фінмарку давні гірські формування, віком понад 3,5 мільярди років. Фактури гір з рельєфами та гротами мають неймовірну колористику хімічних 
вкраплень, створену часом та погодними умовами. Тут домінантою є поєднання океану та землі, тобто крива узбережжя. Саме по цій лінії були визначені всі об'єкти естетичної модернізації простору. Вздовж Варангер фріорду компанія «Biotope» у 2014 році облаштувала кабіни для споглядання за птахами. Таке заняття стає медитаційною практикою сучасної людини, порятунком від депресій урбанізованого середовища. Бюро PUSHAK на каменистому узбережжі виконало двосторонні кабіни-лавочки. Заглиблені дерев'яні конструкції нагадують старі телевізори і своїми бортами захищають сидіння від вітру та, частково, дощу. На сірому пісочному узбережжі Селвіка архітектурне бюро Рейлфа Рамстада у 2013 році розмістило складну конструкцію змієподібної форми з сірого бетону. Доріжки, круглі столи, стіни з вирізами у фрормі кола різних розмірів, закриті та розімкнуті майданчики, всі разом створюють асоціацію з динамікою кільця Удіна. Виключна делікатність входження у ландшафт є визначальною рисою цих проєктів.

Лаконізмом засобів та мінімалізмом естетики вирізняються роботи ландшафтного архітектора Інге Дахлман: це панорамний майданчик на острові Андой (2013), де у відполірованих мармурових сидіннях грає сонце на заході; та панорамний майданчик, кімната відпочинку у фрормі зрізаної хвилі в Хелога (2006). Особливою виразністю та функціональністю вирізняються легкі сходини, які підводять до океанічних хвиль. Новітній дизайн продемонструвало, як завжди, знамените архітектурне бюро Snøhetta у особливому профілі гір Люфутен на Егумі (2007).

Одним зі знакових місць подорожей Норвегією є дорога Тролів, побудована у неймовірно складному гірському масиві в 1936 році. Тоді це була справжня перемога норвежців над природою, згідно з фрілософією часу. І король Хокон своєю присутністю на урочистому відкритті засвідчив велич здійсненого. Архітектурне бюро Рейлфа Рамстада у 2012 році виконало розгалужені панорамні дороги-пандуси над урочищем, де в'ється дорога Тролів. Тут історія та сучасність стали партнерами в організації видовища. Деяка частина бордюрів виконана зі скла, що створює ефект розчиненого простору, заповненого хмарами та туманом. Наче політ з точкою завмирання над прірвою. Складна конструктивна робота частково виконувалась з гелікоптерів, як і на інших об'єктах.

Крім будівництва естетичної інфраструктури, ще одним завданням проєкту $є$ розміщення на кожній дорозі мистецьких творів. У цьому контексті мистецтво розглядалось як коментар та провокатор думок. Кам'яний куб норвезького художника Кнута Волда було встановлено на дорозі Согнеф'єль у 1996 році. Вага об'єкта 42 тонни і транспортування його гірською дорогою було не простим завданням. Це погляд, як на картину - природа у рамі. Об'єкт став знаковим у мистецькому ландшафті Норвегії.

У 2012 році у Валдерсфрю художники зі Швейцарії Петер Фісчлі і Давид Вейсс сорормували об'єкт «Каміння на камінні». На відстані 30 м від дороги лежав звичайний камінь, на нього встановили це один вагою 24 тонни. Побачити витвір можна як з дороги, так і наблизившись до каміння. Інсталяція з двох природних каменів створює ілюзорність грані - це зроблено людиною, чи природою. Художники відмовились зазначати свої імена на об'єкті мистецтва. 
Атлантична дорога $є$ неперевершеним видовищем і туристичним атракціоном, це остання кромка Європи. У 2009 році її визнали найкрасивішою у Норвегії. «Ми прокладаємо дорогу у дощі. Вода проступає крізь. Морські хвилі б'ються об каміння, дощ ллється, вкриваючи ландшафт» (Bengtsson \& Zetterström, 2011, s. 149). Довжина дороги лише 9 км, вона проходить через низку островів і на ній дійсно підвищена концентрація об'єктів, які індукують пейзаж.

Норвезький художник Ян Фрейчен у 2016 році розмістив вздовж океанічної лінії 39 мармурових фррагментів колони і назвав - Трансатлантична колона. Біля води Атлантики, холод якої передається її кольором, на прорізаному вітром та хвилями узбережжі, лежать фрагменти колони, які кожного європейця відсилають до алюзій Давньої Греції. Тоді як для норвежців це відсилка до Ормен Ланге - корабля Улава Трюгвасона, описаного Снорі Стурлусоном. Дорога, складена з великої кількості реальних мостів, провокує історичні рефрлексії та будує фантазійний міст між добою вікінгів та сьогоденням, бо Ормен Ланге, це і назва нафртового родовища. Дійсно, великою мірою ми читаємо картину світу через символи, знаки, асоціації, які є своєрідними дорожніми знаками. I при всій палітрі інтерпретаційного читання, важливо, щоб основні сигнали сприймалися доречно. Це стає випробуванням сучасності у спільному, прозорому інформаційному полі. «Мистецтво уздовж Національних туристичних доріг розповідає мандрівникам неочікувані історії і це додає вражень від ландшафту уздовж дороги. Ці неочікувані ситуації створюють новий простір та можливості для рефрлексій. Це ті враження, які подорожуючі можуть переживати довго після завершення самої подорожі» - вважає С. Рьонінг, куратор артпроєктів у департаменті туризmy (Andersen et al., 2016, s. 255).

Важливо зауважити, що організація цього грандіозного проєкту з корекції культурного ландшафту Норвегії співпала з Національною освітньою програмою, яка акцентується на підвищенні рівня загальних знань та ролі естетичного виховання (Haabesland \& Vavik, 2000, s. 90-123).

\section{- Висновки}

Загальнодержавний проєкт Норвегії по оснащенню Національних туристичних доріг став важливим кроком на шляху формування нового ставлення до інфрраструктури. Проаналізовано основні тенденції роботи з середовищем, найбільш визначні об'єкти дизайну та мистецтва, як складових цих доріг. Зазначено, що сучасне розуміння дороги передбачає наявність таких компонентів: безпеки, комфорту, естетики та екології. Підкреслено, що використання екологічних матеріалів, кольорової гами природи, делікатне входження у природне середовище $є$ найбільш актуальною мовою взаємодії людини та природи у контексті XXI ст.

На підставі системного аналізу та комплексного підходу у вирішенні теми вдалось дійти висновку, що зміна світоглядної парадигми у ставленні до дороги у Норвегії дає підстави говорити про здоров'я та життєздатність нації. Естетична якість архітектурних, дизайнерських і мистецьких об'єктів найвищого ґатунку стала важливим компонентом дорожнього концепту, на ряду з рівнем якості, 
безпеки та комфорту. Можна констатувати, що дорога привчає до естетизму та належного ставлення до навколишнього середовища.

Національні туристичні дороги ще розвиваються. Проте вже зараз можна бачити значні результати - як об'єкти здаються згідно з планом, якісно, надійно та естетично. Виправдовується фрормула Витрувія до архітектури: користь, міцність, краса. Античний світ у цьому сенсі не є забутим. А правила гармонії людини і природи не мають часових та національних обмежень. Вони тільки корелюються часом та простором. Тож проєкт Національних туристичних доріг $€$ своєрідним дзеркалом, у якому відображається Норвегія, теж у розвитку. Проєкт є виразною формою демонстрації ії̈ культурного ландшафту, що отримав розголос на міжнародній арені. А ми є свідками реалізації великої стратегічної ідеї, блискучого прикладу зустрічі культури з ландшафтом.

\section{- Список використаних джерел}

Andersen, J., Hjeltnes, A., Larsen, J. K., Hølmebakk, S., \& Rønning, S. (2016). Nasjonale turistveger. Press.

Bengtsson, S., \& Zetterström, J. (2011). Design by Nature.Orfeus publishing.

Bull, T., \& Norvik, H. (Red.). (2004). Norge - portrett av en nasjon. Dinamo Forlag.

Fitz, A., \& Krasny, E. (2019). Critical Care. Architecture and Urbanism for a Broken Planet. MIT Press.

Haabesland, A., \& Vavik, R. (2000). Kunst og håndverk - hva og hvorfor. Fagbokforlaget.

Hessen, D. O. (2016). Landskap i endring. Pax forlag.

\section{- References}

Andersen, J., Hjeltnes, A., Larsen, J. K., Hølmebakk, S., \& Rønning, S. (2016). Nasjonale turistveger [National tourist roads]. Press [in Norwegian].

Bengtsson, S., \& Zetterström, J. (2011). Design by Nature. Orfeus publishing [in English].

Bull, T., \& Norvik, H. (Red.). (2004). Norge - portrett av en nasjon [Norway - portrait of a nation]. Dinamo Forlag [in Norwegian].

Fitz, A., \& Krasny, E. (2019). Critical Care. Architecture and Urbanism for a Broken Planet. MIT Press [in English].

Haabesland, A., \& Vavik, R. (2000). Kunst og håndverk - hva og hvorfor [Arts and crafts what and why]. Fagbokforlaget [in Norwegian].

Hessen, D. O. (2016). Landskap i endring [Landscape in change]. Pax forlag [in Norwegian]. 


\title{
- THE ROAD AS A PART OF NORWAY'S CULTURAL LANDSCAPE: CULTURE SHIFT
}

\author{
- Olena Som-Serdiukova \\ - PhD in Art Studies, Associate Professor, \\ ORCID: 0000-0001-5196-545X, e-mail: olenasom@gmail.com, \\ Kyiv National University of Culture and Arts, \\ Kyiv, Ukraine
}

\section{- Abstract}

The purpose of the article is to describe the trends, particular qualities and functions of Norway's roads which are parts for cultural landscape development. The research methodology is based on a multidisciplinary approach. This allowed the integration of several methods, including analytical, systematic, interpretive, descriptive, and diachronic, to emphasise the socio-historical context and to study a road as a civilisational phenomenon, where culture and nature meet via a dialogue. The scientific novelty of the work lies in the fact that for the first time in Ukrainian science, it examines the phenomenon of national tourist roads in Norway as an organisational factor of the cultural landscape. Conclusions. Today in Norway, the roads require convenience, safety, comfort, ethics interaction of road users, knowledge of the cultural landscape, aesthetics and entertainment. Their value for society is activated, accumulated, and actualised. Therefore, it was selected the most impressive examples for the project, where attention is paid to their specificity and originality. Unique items of design and art are offered by corresponding with the uniqueness of nature, precisely to increase its expressiveness. Various methods of subtle visions into nature, demonstrating the transition of culture against the background of eternity have been analysed. Since local and international tourism as a form of leisure time is developing rapidly, it influences the development of tourist roads which stimulates the growth in infrastructure. Their fundamental function is undertaken, and it lies through ecology, information, design, and art. This new form of attitude towards roads does not imply the previously prevailing pragmatic approach. It is noted that changes in society have left a deep imprint, which led to the renewed functions on the road. To solve new approaches, various highly qualified specialists collaborated to achieve the realisation of the idea when the road is combined with logic, aesthetics, and emotions. Their modern solutions got approved, and the Norwegian national project succeeded and expanded the road function. This experience goes beyond the scope of the national project in its significance.

Keywords: tourist road; cultural landscape; design; art; nature; environment 


\title{
ДОРОГА КАК ЧАСТЬ КУЛЬТУРНОГО ЛАНДШАФТА НОРВЕГИИ: ИЗМЕНЕНИЕ МИРОВОЗЗРЕНЧЕСКОЙ ПАРАДИГМЫ
}

\author{
- Сом-Сердюкова Елена Николаевна \\ - Кандидат искусствоведения, доцент, \\ ORCID: 0000-0001-5196-545X, e-mail: olenasom@gmail.com, \\ Киевский национальный университет культуры и искусств, \\ Киев, Украина
}

\section{Аннотация}

Цель статьи - определить тенденции, особенности и функции дорог Норвегии, которые являются частью формирования культурного ландшафта. Исследование построено на междисциплинарном подходе и использовании таких методов, как: аналитический, систематический, интерпретационный, описательный и диахронный - для подчеркивания социально-исторического контекста и раскрытия явления дороги как цивилизационного френомена, где встречаются культура и природа в фрорме диалога. Научная новизна работы заключается в том, что в ней впервые в отечественной науке исследован феномен Национальных туристических дорог Норвегии, как организационного фактора культурного ландшафта. Выводы. В современной Норвегии к дорогам предъявляются требования: удобства, безопасности, комфорта, этики взаимодействия участников движения, познания культурного ландшафта, эстетики, зрелища. Их значимость для общества активизируется, аккумулируется и актуализируется. Охарактеризованы наиболее выразительные проекты, уделено внимание их специфике и оригинальности. Уникальности природы предложены уникальные объекты дизайна и искусства, именно для повышения ее выразительности. Проанализированы различные способы деликатного вторжения в природу, демонстрирующие транзитивность культуры на фоне вечности. Локальный и международный туризм как форма досуга стремительно набирает обороты, а развитие туристических дорог стимулирует инфраструктуру. Их фуннция понимается через экологию, информацию, дизайн, искусство. Такое отношение к дорогам предполагает не прагматичный подход, который доминировал раньше. Отмечено, что изменения в обществе повлияли на понимание функции дороги. На современном этапе ее жизнедеятельность обеспечивается специалистами различного профиля и доказывает необходимость ее понимания в синтезе логики, эстетики и эмоции. В ходе исследования доказана значимость общегосударственного проекта Норвегии по усовершенствованию и расширению функции дороги. Определено, что этот опыт по своему значению перерастает границы национального проекта.

Ключевые слова: туристическая дорога; культурный ландшафт; дизайн; искусство; природа; среда 